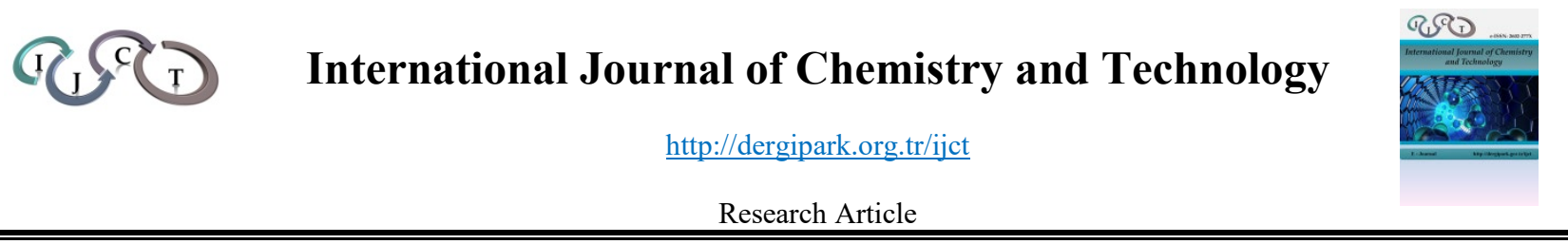

\title{
Antifungal effect of some essential oil combinations
}

\author{
Musa TÜRKMEN ${ }^{1 *}$, (D) Durmuş Alpaslan KAYA ${ }^{1}$ \\ ${ }^{1}$ Hatay Mustafa Kemal University, Department of Field Crop, Hatay 31000, Turkey
}

Received: 17 April 2021; Revised: 14 May 2021; Accepted: 14 May 2021

*Corresponding author e-mail: turkmenmusa@hotmail.com

Citation: Türkmen, M.; Kaya, D. A. Int. J. Chem. Technol. 2021, 5 (1), 6-10.

\section{ABSTRACT}

In the present study, in vitro antifungal effect of the essential oils was examined against soil-borne (Sclerotinia sclerotiorum) pathogens. Essential oils obtained from Foeniculum vulgare and Laurus nobilis plants, naturally growing in the Hatay province, Turkey. The volatile phase of essential oils at different concentrations inhibited the mycelial growth in the dependent of dose. While the fungitoxic effect of essential oils was determined as $7.50 \mu \mathrm{L}$ in laurel essential oil, it was determined as $5.0 \mu \mathrm{L}$ in fennel essential oils. Laurel essential oils exhibited fungicidal effect at $15 \mu \mathrm{L}$ whereas. Fennel essential oils exhibited fungicidal effect at $7.50 \mu \mathrm{L}$. The two essential oils were combinated by 3 different techniques (manually combinated oils; together distillation of oils; using solvent and combinated oils) and were applied against $S$. sclerotiorum disease agents. As a conclusion, the results exhibited that laurel and fennel obtained separately by manually mixing with suitable combination of essential oils (MF\%75L\%25 ) showed fungicidal effect at $5.0 \mu \mathrm{L}$; laurel and fennel essential oil obtained by distilling the mixture ( $\mathrm{T}$ $\mathrm{F} \% 75 \mathrm{~L} \% 25$ ) exhibited fungicidal effect at $3.75 \mu \mathrm{L}$ concentrations and laurel and fennel essential oils with appropriate combination and mixture with hexane (SF\%75L\%25) exhibited fungicidal effect at $3.75 \mu \mathrm{L}$. Antimicrobial activities revealed that the essential oils in appropriate combinations are more effective than their using alone against fungal disease agents.

Keywords: Antifungal effect, Essential oil, Fennel, Laurel.
Bazı uçucu yağ kombinasyonlarının antifungal etkisi

ÖZ

$\mathrm{Bu}$ çalışmada, Türkiye'nin Hatay ilinin farklı bölgelerinde doğal olarak yetişen Foeniculum vulgare ve Laurus nobilis gibi farklı bitkilerden elde edilen uçucu yağların, toprak kaynaklı fungal (Sclerotinia sclerotiorum) hastalık etkenlerine karşı in vitro antifungal etkinliği araştırılmıştır. Farklı konsantrasyonlardaki uçucu yağların buhar fazı, doza bağlı bir şekilde miselyal gelişimini inhibe etmiştir. L. nobilis uçucu yağlarının uçucu fazları $7.50 \mu \mathrm{L}$ 'de fungitoksik etki ve $15 \mu \mathrm{L}$ 'de fungisidal etki gösterirken; $F$. vulgare uçucu yağları $5.0 \mu \mathrm{L}$ konsantrasyonda fungitoksik etki ve $7.50 \mu \mathrm{L}$ 'de fungisidal etki göstermiştir. İki uçucu yağ, 3 farklı yöntem kullanılarak karıştırılmış (elle iki uçucu yağ karıştırılmış; yağlar birlikte damıtılarak karıştırılmış ve çözücü kullanılarak karıştırılmış) ve Sclerotinia sclerotiorum patojenlerine karşı test edilmiştir. Sonuçlar, ayr1 ayr1 elde edilen L. nobilis ve $F$. vulgare' nin elle karıştırılmasıyla elde edilen uygun uçucu yă kombinasyonunun (M-F\% 75L\% 25) $5.0 \mathrm{uL}$ 'de fungisidal etki gösterdiğini; $L$. nobilis ve $F$. vulgare' nin birlikte damitılmasıyla elde edilen kombinasyonunun (T-F\%75L\%25) $3.75 \mu \mathrm{L}$ konsantrasyonda fungisidal etki gösterdiğini ve $L$. nobilis ve $F$. vulgare uçucu yağlarının uygun kombinasyonunun hekzanla karıştırılmasıyla (S-F\% 75L\% 25) $3.75 \mathrm{uL}$ 'de fungisidal etki gösterdiğini ortaya koymuştur. Antimikrobiyal aktiviteler, uygun kombinasyonlardaki uçucu yağların mantar hastalık etkenlerine karşı tek başlarına kullanılmasından daha etkili olduğunu ortaya çıkarmıştır.

Anahtar Kelimeler: Antifungal Etki, Uçucu Yağ, Rezene, Defne.

\section{INTRODUCTION}

Food firms admit that shelf life, nutrition and microbial quality of food yield are important for them. Synthetic pesticides have been usually used to preserve food and extend the shelf-life of food products. But these synthetic pesticides can rise health problems for consumers in a long term period. ${ }^{1}$ Therefore food processors and consumers have expressed a wish to decrease the use of synthetic chemicals in food protection. ${ }^{2-5}$ Chemical 
fertilizers should be applied at appropriate doses according to the programs prepared according to the results of the analysis of the control experts and high efficiency should be achieved by reducing the negative effects on the environment. ${ }^{6}$ In the selection of plant species and varieties, the ecological conditions of the region where the production will be made and the possibility of getting the diseases at the lowest level under these conditions should be taken into consideration. ${ }^{7}$ Extreme pesticide usage, which threatens ecological and human health in recent years, and increasing prices have created the need for alternative ways a fight with diseases. ${ }^{8}$ It has directed the researchers to the usage of essential oils and plant extracts due to their less negative effects on human health and environmental safety. ${ }^{9,10}$ The plants have been used by humans since the early ages for food, spices and medical purposes. The development in the pharmaceutical industry in parallel with chemistry in the18th century, caused substitution of plants with synthetic and semi-synthetic materials. ${ }^{11}$ Essential oils have long time served as flavoring agents in food and beverages. Recently, essential oils are taking increasing attention because of their antimicrobial effects. ${ }^{12}$ Extract and essential oils that are obtained from plants in different ways, have been proved to have antifungal activities. ${ }^{13}$ Moreover, recently, several studies have been reported on the antifungal activity of essential oils against fungal pathogens ${ }^{14-17}$ and it was shown that the antifungal effects of essential oil depend on the composition of essential oils. ${ }^{18}$ Although there are numerous reports on the antifungal activities of essential oils, in vitro conditions ${ }^{19}$ there is no research devoted to the use of different methods of combination of essential oils. In this study; essential oils obtained from Foeniculum vulgare Mill and Laurus nobilis L which commonly grown in Hatay province ${ }^{20,21}$ and essential oils combinations obtained in different ways have been studied in in vitro conditions as means of an alternative way to chemical fight against Sclerotinia sclerotiorum fungal pathogen factor which is an important problem in plants.

\section{MATERIALS AND METHODS}

\subsection{Plant material}

In our study, the essential oils were obtained from the leaves of Laurel (Laurus nobilis L.) and the seeds of fennel (Foeniculum vulgare Mill.). Both plants have antimicrobial effects and they are naturally grown in Hatay province.

\subsection{Essential Oil Extraction}

Hydrodistillation was used for the plant material dried at room temperature. It was weighed and placed in a round bottom flask with a volume of distilled water (the solvent); Essential oils from dry Laurus nobilis L. plant leaves and Foeniculum vulgare seeds were obtained by hydro distillation for $3 \mathrm{~h}$ with Clevenger's apparatus. The oils were separated, dried over anhydrous sodium sulphate and stored in an amber bottle at $4{ }^{\circ} \mathrm{C}$ until used.

\subsection{Obtaining the Essential Oils mixtures}

Three different methods have been adopted to obtain essential oil mixtures. Firstly, the $F$. vulgare and $L$. nobilis essential oils obtained separately in Clevenger have been mixed in specific ratios [Foeniculum vulgareLaurus nobilis (75\%-25\%), (50\%-50\%), (25\%-75\%)], the essential oil mixtures obtained have been applied to $S$. sclerotiorum pathogen, planted onto Petri dishes, in different concentrations. Afterward, mixtures of $F$. vulgare and L. nobilis essential oils in suitable ratio have been obtained by putting them into carboys together at Clevenger evenly [Foeniculum vulgare-Laurus nobilis] and different concentrations of this mixture have been applied to pathogen.

Finally, the $F$. vulgare and L. nobilis essential oils obtained separately at Clevenger have been diluted separately with hexane at 2:1 ratio and by taking from $F$. vulgare-hexane and L. nobilis-hexane different volumes, mixtures in specific ratios $[F$. vulgare-L. nobilis $]$ were obtained and further applied to S. Sclerotiorum pathogen.

\subsection{Test of the Micro-organisms}

The S. sclerotiorum used in this study was isolated from infected tomato stalks, which showed symptoms of Sclerotinia root rot. The surface disinfected sclerotia was coated by antibiotic modified potato dextrose agar. Plates were incubated at $20{ }^{\circ} \mathrm{C}$ for 5-7 days to allow growth of mycelium in the medium. Small agar blocks containing hyphal ends were cut at colony borders and transferred to potato dextrose agar (PDA). Replicate plates were incubated at $20^{\circ} \mathrm{C}$. The fungal isolate was re-inoculated into the tomato seedling and found to be highly pathogenic. ${ }^{9}$

\subsection{Determination of the Antifungal Activities of Essential Oils}

To determine the antifungal activities of essential oils from fennel and laurel plants and suitable mixtures of these oils, the culture of the 7-days old S. sclerotiorum isolate was placed in the center of the $9 \mathrm{~cm}$ diameter sterile Petri dish containing PDA medium (autoclaved for 15 minutes at $121^{\circ} \mathrm{C}$ ). S. sclerotiorum isolate was taken with a $5 \mathrm{~mm}$ fungus drill. Different doses of essential oils were added to sterile filter papers $(10 \mathrm{~mm}$ diameter, Whatman No. 1) placed into Petri dishes. The Petri dish was covered with parafilm to prevent the loss of essential oils and incubated at $24-25^{\circ} \mathrm{C}$. Pure water was added to the Petri dishes. Evaluations were made by measuring colony radial growth diameters (in $\mathrm{mm}$ ) when growth of fungi in the control Petri dish was completed. The 
blocking ratio $(\%)$ at different concentrations of each essential oil was calculated according to Abbott formula. ${ }^{1}$

Blocking $(\%)=\frac{F G K-F G U}{F G K} \times 100$

$\mathrm{FGK}=$ Fungal growth in control oils $(\mathrm{mm})$

$\mathrm{FGU}=$ Diameter of fungal growth in treated Petri dishes (mm)

\subsection{Determination of the Fungicidal and Fungistatic Effect of Essential Oils}

The in vitro antifungal volatile phase effects of essential oils against $S$. sclerotiorum were determined against mycelial growth. The single spore culture of each fungal isolates were grown on Potato Dextrose Agar (PDA) medium at $25^{\circ} \mathrm{C}$ for $3-5$ days. İn consequence, all the essential oils used in the experiments revealed not to have micelle development although the covers were replaced at the concentrations in which $100 \%$ interception was

plant essential oils on fungal micelle development, different concentrations of essential oils obtained from Laurus nobilis and Foeniculum vulgare plants and different concentrations of proper mixtures of these oils obtained via different methods have been applied on $S$. sclerotiorum pathogen to identify the volatile effects.

3.2. Activities of Laurus nobilis and Foeniculum vulgare Plant Essential Oils on Fungal Development

The results obtained for the experiments concerning the volatile effect of Foeniculum vulgare and Laurus nobilis essential oils are given in Table 1. As it is seen in Table 1 , with the increase of the concentrations of essential oils, micelle developments of the funguses decrease. Comparing the two essential oils studied the results obtained showed that the essential oil of fennel was more inhibitory to $S$. sclerotiorum than laurel essential oil. As it can be seen in Table $1, S$. sclerotiorum micelles covered the entire Petri dish $(90 \mathrm{~mm})$ in both applications

observed, hence it has been determined that essential oils effect on fungus at mentioned concentrations are fungicidal (completely disrupter, fatal).

\subsection{Statistical analysis}

All in vitro experiments were established according to a randomized plot design. The experiment was established with 3 replicates, each Petri dish being one repeat. This trial was repeated twice The variance analysis was performed with one-way ANOVA using SPSS statistical program (SPSS Inc., version 11.5.0) without converting the obtained measurement values to $\%$ and the differences between the concentrations were determined by Duncan Multiple Comparison Test $(\mathrm{p} \leq 0.05)$.

\section{RESULTS AND DISCUSSION}

3.1. Activities of Laurus nobilis and Foeniculum vulgare Plant Essential Oils on Fungal Development

Within the study intended to research volatile effects of at control doses. In Table 1 , the numbers represent the diameter covered by mycelial development. Micelle development was determined as $35.00 \mathrm{~mm}$ at $2.50 \mu \mathrm{L}$ dose for fennel essential oil and it was determined that it inhibits $61.20 \%$ of micelle development. The micelle development of fungus at a dose of $3.75 \mu \mathrm{L}$ of fennel essential oil was found to be $6.70 \mathrm{~mm}$, and at this concentration, it was found that essential oil inhibits the micelle development of $92.56 \%$. It was determined that the mycelial growth of the fungus was not seen at $5.00 \mu \mathrm{L}$ dose of fennel essential oil meaning that this essential oil showed fungistatic effect and it can be concluded that fennel essential oil prevents the mycelial growth at this dose. Instead at the higher dose $(7.5 \mu \mathrm{L})$ it has been determined that it shows fungicidal effect. When the effectiveness of laurel essential oil on micelle development was examined, it was determined that it showed fungistatic effect for a dose of $7.50 \mu \mathrm{L}$. and fungicidal effect for a dose of $15.00 \mu \mathrm{L}$.

Table 1. The activity of different essential oils at different doses on S. sclerotiorum micelle development

\begin{tabular}{lll}
\hline Essential oils & & \\
\hline Dose $(\boldsymbol{\mu L})$ & Foeniculum vulgare & Laurus nobilis \\
\hline $\mathbf{0}$ & $90.00 \mathrm{~d}$ & 90.00 \\
$\mathbf{2 . 5 0}$ & $35.00 \mathrm{cA}$ & $90.00 \mathrm{~B}$ \\
$\mathbf{3 . 7 5}$ & $6.70 \mathrm{bA}$ & $90.00 \mathrm{~B}$ \\
$\mathbf{5 . 0 0}$ & $0.00 \mathrm{aA} *$ & $90.00 \mathrm{~B}$ \\
$\mathbf{7 . 5 0}$ & $0.00 \mathrm{a}^{* *}$ & $0.00^{*}$ \\
$\mathbf{1 0 . 0 0}$ & $0.00 \mathrm{a}$ & $0.00^{*}$ \\
$\mathbf{1 2 . 5 0}$ & $0.00 \mathrm{a}$ & $0.00^{*}$ \\
$\mathbf{1 5 . 0 0}$ & $0.00 \mathrm{a}$ & $0.00^{* *}$ \\
\hline
\end{tabular}

*the dose showing fungistatic effect; ** the dose showing fungicidal effect; the rates in the column are the average of the rates in 3 different Petris dishes and they have been repeated at 3 different times. Small letters next to the rates in the same column (Difference between doses in the effectiveness of different doses of essential oils on micelle development) or capital letters next to the rates in the 
same line (The difference between oils in the effectiveness of the same doses of fennel and laurel essential oils on mycelial development) shows that the differences among applications are not statistically significant (Duncan's Multiple Range Test, $\mathrm{p} \leq 0,05$ ).

\subsection{Determination of the Effectiveness of Essential Oils Mixtures on Micelle Development of Fungal Agents Under in vitro Conditions}

As it can be seen from Table 2, with increasing concentrations of essential oils, the effectiveness of essential oils on the pathogen micelle development has increased. It has been observed that the mixture showing the most fungitoxic effect is the mixture containing more Foeniculum vulgare plant essential oil concentration. It was observed that the essential oil mixture obtained as a result of distillation of plants together $(\mathrm{T})$ in the same bottom flask had more effect on mycelial growth at lower concentrations than the mixture with hexane solvent $(\mathrm{S})$ and the essential oils obtained separately (M) from the plants. M-F\%50L\%50 and M-F\%75L\%25 essential oil mixtures showed fungistatic effect for a dose of $3.75 \mu \mathrm{L}$ and fungicidal effect for a dose of $5 \mu \mathrm{L}$. M-F $\% 25 \mathrm{~L} \% 75$ essential oil mixture showed fungistatic effect for a dose of $5 \mu \mathrm{L}$ and $7.50 \mu \mathrm{L}$, while it showed fungicidal effect for a dose of $10 \mu \mathrm{L}$. T-F $\% 50 \mathrm{~L} \% 50$ was found to have fungistatic effect for a dose of $3.75^{\prime} \mu \mathrm{L}$ while it was observed to have fungicidal effect for a dose of $5 \mu \mathrm{L}$. TF\%75L\%25 essential oil mixture showed fungicidal effect for a dose of $3.75 \mu \mathrm{L}$. T-F\% $\% 25 \mathrm{~L} \% 75$ essential oil mixture showed fungistatic effect the doses of 3.75 and 5 $\mu \mathrm{L}$, while it showed fungicidal effect for a dose of 7.50 $\mu \mathrm{L}$. S-F\%50L\%50 essential oil mixture showed fungistatic effect for the doses 3.75 and $5 \mu \mathrm{L}$, while it showed fungicidal effect for a dose of $7.50 \mu \mathrm{L}$. It was seen that $\mathrm{S}-\mathrm{F} \% 75 \mathrm{~L} \% 25$ essential oil mixture had fungicidal effect for a dose of $3.75 \mu \mathrm{l}$ while S$\mathrm{F} \% 25 \mathrm{~L} \% 75$ essential oil mixture had fungicidal effect for a dose of $5 \mu \mathrm{L}$. The results that have been conducted to determine the volatile effects of essential oils are given in Table 2.

Table 2. Determination of the effectiveness of essential oils mixtures (F: Foeniculum vulgare, L: Laurus nobilis) on micelle development of fungal agents under in vitro conditions

\begin{tabular}{|c|c|c|c|c|c|c|}
\hline \multirow[b]{2}{*}{ Mixtures } & \multicolumn{6}{|c|}{ Doses $(\mu \mathrm{L})$} \\
\hline & $\mathbf{0}$ & 2.50 & 3.75 & 5.00 & 7.50 & 10.0 \\
\hline M-F\%50L\%50 & $90.00 \mathrm{c}$ & $11.67 \mathrm{bA}$ & $0.00 \mathrm{aA}^{*}$ & $0.00 \mathrm{a}^{* *}$ & $0.00 \mathrm{a}$ & $0.00 \mathrm{a}$ \\
\hline M-F\%75L\%25 & $90.00 \mathrm{c}$ & $7.67 \mathrm{bA}$ & $0.00 \mathrm{aA} *$ & $0.00 \mathrm{a}^{* *}$ & $0.00 \mathrm{a}$ & $0.00 \mathrm{a}$ \\
\hline M-F $\% 25 \mathrm{~L} \% 75$ & $90.00 \mathrm{~d}$ & $59.00 \mathrm{cD}$ & $31.33 \mathrm{bC}$ & $0.00 \mathrm{a}^{*}$ & $0.00 \mathrm{a}^{*}$ & $0.00 \mathrm{a}^{* *}$ \\
\hline T-F\%50L\%50 & $90.00 \mathrm{c}$ & $9.33 \mathrm{bA}$ & $0.00 \mathrm{aA} *$ & $0.00 \mathrm{a}^{* *}$ & $0.00 \mathrm{a}$ & $0.00 \mathrm{a}$ \\
\hline T-F\%75L\%25 & $90.00 \mathrm{c}$ & $17.33 \mathrm{bB}$ & $0.00 \mathrm{aA} * *$ & $0.00 \mathrm{a}$ & $0.00 \mathrm{a}$ & $0.00 \mathrm{a}$ \\
\hline T-F $\% 25$ L $\% 75$ & $90.00 \mathrm{c}$ & $9.00 \mathrm{bA}$ & $0.00 \mathrm{aA}^{* *}$ & $0.00 \mathrm{a}^{*}$ & $0.00 \mathrm{a}^{* *}$ & $0.00 \mathrm{a}$ \\
\hline S-F\%50L\%50 & $90.00 \mathrm{c}$ & $36.67 \mathrm{bC}$ & $0.00 \mathrm{aA} * *$ & $0.00 \mathrm{a}^{*}$ & $0.00 \mathrm{a}^{* *}$ & $0.00 \mathrm{a}$ \\
\hline S-F\%75L\%25 & $90.00 \mathrm{c}$ & $19.67 \mathrm{bB}$ & $0.00 \mathrm{aA} * *$ & $0.00 \mathrm{a}$ & $0.00 \mathrm{a}$ & $0.00 \mathrm{a}$ \\
\hline S-F\%25L\%75 & $90.00 \mathrm{~d}$ & $40.00 \mathrm{cC}$ & $13.33 \mathrm{bB}$ & $0.00 \mathrm{a}^{* *}$ & $0.00 \mathrm{a}$ & $0.00 \mathrm{a}$ \\
\hline
\end{tabular}

*the dose showing fungi static effect; **the dose showing fungicidal effect. The experiment has been repeated at 3 different times and the values in the column represents the inhibition rates and they are the average of the values obtained for 3 different Petri dishes. Capital letters next to the average inhibition rates in the same column (Difference between doses in the effectiveness of different doses of essential oils on micelle development) or small letters next to the rates in the same line (The difference between oils in the effectiveness of the same doses of fennel and laurel essential oils on mycelial development) show that the differences among applications are not statistically significant (Duncan's Multiple Range Test, $\mathrm{p} \leq 0,05$ ).

\section{CONCLUSIONS}

This study suggests that essential oils have the potential for use in the control of soil-borne fungal disease agents such as $S$. sclerotiorum. It has been determined that essential oil mixtures show synergistic effect against pathogen and the effects of essential oil mixtures, especially the mixture obtained by distilling Foeniculum vulgare and Laurus nobilis plants together, on the development of pathogen are quite promising. The essential oils and their mixtures used in this study could be considered as potential alternatives for synthetic fungicides.

\section{ACKNOWLEDGEMENTS}

This work has been produced from the master thesis.

\section{Conflict of interests}

I declare that there is no a conflict of interest with any person, institute, company, etc.

\section{REFERENCES}

1. Ghabraie, M.; Vu, K.D.; Tata, L.; Salmieri, S.; Lacroix, M. LWT-Food Sci.Technol, 2016, 66, 332-339. 
2. Conner, D.E; Beuchat, L.R. J. Food Sci, 1984, 49, 29 434.

3. Deans, S.G.; Ritchie, G. Int.J. Food Microbiol, 1987, 165-180.

4. Beuchat, L.R.; Dillon, V.M.; Board, R.G., CAB International Wallingford, UK, 1994, 167-180.

5. Delaquis, P.J.; Stanich, K.; Girard, B.; Mazza, G. Int.J. Food Microbiol, 2002, 74, 101-109.

6. Çalık, A. Gece Academy. Innovative Approaches in Agriculture, Forestry and Aquaculture Sciences. 2018, 101-105.

7.Çalık, A. Turkish JAF Sci.Tech., 2020, 8(3): 728-732.

8. Paster, N.; Bullerman, L.B., Int.J. Food Microbiol, 1988, 7, 257-265.

9. Soylu, E.M.; Tok, M.F.; Soylu, S.; Kaya, A.D.; Evrendilek, G.A. Pak. J. Biol. Sci, 2005, 8, 25-29.

10. Soylu, S.; Yigitbas, H.; Soylu, E.M.; Kurt, S. Journal of Applied Microbiology, 2007,103, 1021-1030.

11. Altinok-Yipel, F.; Yipel, M. Türk Veteriner Hekimler Birliği Dergisi, 2014, 1(2): 79-82.

12. Burt, S. Int.J. Food Microbiol, 2004, 94, 223-253.

13. Toroğlu, S.; Cenet, M. KSÜ Fen ve Mühendislik Dergisi, 2006, 9(2), 12-20.

14. Edris, A.E.; Farrag, E.S. Nahrun//Food, 2003, 47, 117-121.

15. Kalemba, D.; Kunicka, A. Curr. Med. Chem, 2003, $10,813-829$.

16. Pitarokili, D.; Tzakou, O.; Loukis, A.; Harvala, C. J Agric Food Chem, 2003, 51, 3294-3301.

17. Kara, M.; Soylu, S.; Türkmen, M.; Kaya, D.A. Journal of Tekirdag Agricultural Faculty, 2020, 17(2), 264-275.

18. Niculescu, O.; Gaidau, C.; Simion, D.; Daniela Berechet, M. Revista De Chimie (Bucharest), 2020, 71(1), 445-449.

19. Deleanu, M.; Popa, E.E.; Popa M.E. Revista De Chimie (Bucharest), 2018,69(8), 1927-1933.

20. Koçer, O.; Ayanoğlu, F. International Journal of Eastern Anatolia Science Engineering and Design, 2021, 3 (1), 72-88.
21. Ayanoğlu, F.; Kaya, D.; Koçer, O. Int. J. Chem. Technol, 2018, 2 (2), 161-167. 